\title{
Effect of Fixed Orthodontic Treatment on Salivary Nickel and Chromium Levels: A Systematic Review and Meta-Analysis of Observational Studies
}

\author{
Mohammad Moslem Imani ${ }^{1}$, Hamid Reza Mozaffari ${ }^{2,3}$, Mazaher Ramezani ${ }^{4}$ and \\ Masoud Sadeghi ${ }^{3,5, *(D)}$ \\ 1 Department of Orthodontics, Kermanshah University of Medical Sciences, Kermanshah 6713954658, Iran; \\ m.imani@kums.ac.ir \\ 2 Department of Oral and Maxillofacial Medicine, School of Dentistry, Kermanshah University of Medical \\ Sciences, Kermanshah 6713954658, Iran; mozaffari@kums.ac.ir \\ 3 Medical Biology Research Center, Kermanshah University of Medical Sciences, \\ Kermanshah 6714415185, Iran \\ 4 Molecular Pathology Research Center, Imam Reza Hospital, Kermanshah University of Medical Sciences, \\ Kermanshah 6714415153, Iran; m_ramezani@kums.ac.ir \\ 5 Students Research Committee, Kermanshah University of Medical Sciences, Kermanshah 6715847141, Iran \\ * Correspondence: sadeghi_mbrc@yahoo.com or msadeghi@kums.ac.ir
}

Received: 17 December 2018; Accepted: 20 February 2019; Published: 1 March 2019

\begin{abstract}
Nickel and chromium ions released from fixed orthodontic appliances may act as allergens. This study aimed to systematically review the effect of fixed orthodontic treatment on salivary levels of these ions by doing a meta-analysis on cross-sectional and cohort studies. The Web of Science, Scopus, Cochrane Library, and PubMed databases were searched for articles on salivary profile of nickel or chromium in patients under fixed orthodontic treatment published from January 1983 to October 2017. A random-effect meta-analysis was done using Review Manager 5.3 to calculate mean difference (MD) and $95 \%$ confidence interval (CI), and the quality of questionnaire was evaluated by the Newcastle-Ottawa scale. Fourteen studies were included and analyzed in this meta-analysis. Salivary nickel level was higher in periods of $10 \mathrm{~min}$ or less $(\mathrm{MD}=-11.5 \mu \mathrm{g} / \mathrm{L}, 95 \% \mathrm{CI}=-16.92$ to $-6.07 ; P<0.0001)$ and one day (MD $=-1.38 \mu \mathrm{g} / \mathrm{L}, 95 \% \mathrm{CI}=-1.97$ to $-0.80 ; P<0.00001)$ after initiation of treatment compared to baseline (before the insertion of appliance). Salivary chromium level was higher in periods of one day ( $\mathrm{MD}=-6.25 \mu \mathrm{g} / \mathrm{L}, 95 \% \mathrm{CI}=-12.00$ to $-0.49 ; P=0.03)$ and one week ( $\mathrm{MD}=-2.07 \mu \mathrm{g} / \mathrm{L}, 95 \% \mathrm{CI}=-3.88$ to $-0.26 ; P=0.03$ ) after the initiation of treatment compared to baseline. Corrosion of fixed orthodontic appliances leads to elevated salivary nickel and chromium concentrations early after initiation of orthodontic treatment. Randomized clinical trials controlling for factors affecting the saliva composition are recommended on a higher number of patients and among different ethnicities.
\end{abstract}

Keywords: Orthodontic appliances; saliva; nickel; chromium; meta-analysis

\section{Introduction}

Orthodontic appliances are highly biocompatible, although some side effects associated with the release of nickel ions have been documented [1]. Fixed orthodontic appliances including brackets and arches are commonly made of stainless steel and nickel-titanium (NiTi) alloys and, therefore, have corrosion potential in the oral environment [2]. The amount of nickel as the main constituent of contemporary orthodontic appliances [3] may vary from $8 \%$ in stainless steel $[4,5]$ to more than $50 \%$ in NiTi alloys [4]. Stainless-steel alloys include $17 \%$ to $22 \%$ of chromium [6]. Fixed orthodontic 
treatment causes major changes in the composition of the saliva [7]. Nickel and chromium ions released from fixed orthodontic appliances can serve as allergens or may have serious biological side effects $[2,6]$. Moreover, they are cytotoxic, mutagenic, and carcinogenic in small quantities in the range of nanograms [2]. Evaluation of the level of trace elements in patients using orthodontic appliances is a priority [8]. Both nickel and chromium ions can cause hypersensitivity reactions in some people [9]. In addition, nickel and chromium can cause dermatitis and asthma [10]. Increased prevalence of nickel hypersensitivity as well as the increased demand and availability of orthodontic treatment have attracted the attention of researchers towards the composition of alloys and their ion release potential during orthodontic treatment [9]. Orthodontic appliances (brackets and wires) exposed to the oral environment are affected by thermal alterations in the oral cavity and $\mathrm{pH}$, constant presence of saliva, exposure to foods and drinks, mechanical loads applied to them, and abrasion. They are subjected to aging as such and may undergo dissolution or oxidation $[1,11,12]$. The placement of archwires can cause an increase in salivary nickel and chromium levels and, therefore, nickel may be released from the wires $[7,13]$ as well as bands and brackets [13]. Daily oral intake of nickel from food is estimated to be 200-300 to $600 \mu \mathrm{g} /$ day $[1,14]$. The average dietary intake of chromium is estimated to be 50-200 $\mu \mathrm{g} /$ day [15]. In vitro nickel release from orthodontic appliances was reported to be $22-40 \mu \mathrm{g} /$ day, which was lower than the estimated dietary intake [5]. The inherent heterogeneity of metal alloys and their use in combination with other alloys, microconversion, the forces acting on the appliances, and the friction between wires and brackets may further add to the corrosion process [16]. Therefore, in orthodontic practice, it is essential to know the exact amount of each ion released during the course of treatment, and inform the patient undergoing orthodontic treatment in this respect [2].

Controversy exists regarding the reported values of nickel and chromium ions released during fixed orthodontic treatment in previous studies; therefore, we decided to systematically review the previous studies on the effect of fixed orthodontic treatment on salivary levels of nickel and chromium ions in a meta-analysis of observational studies.

\section{Materials and Methods}

This meta-analysis was done according to the guidelines for the preferred reporting items for systematic review and meta-analysis (PRISMA) [17].

\subsection{Search Strategy}

We searched the Web of Science, Scopus, Cochrane Library, and PubMed databases for articles on assessment of salivary profiles of nickel or chromium in patients under orthodontic treatment using the search terms "nickel or chromium", "orthodontic", and "saliva or salivary". The search was limited to human studies accessible in PubMed, Web of Science, and Scopus published from January 1983 to October 2017.

\subsection{Study Selection}

Articles on evaluation of salivary profile of nickel or chromium in patients under fixed orthodontic treatment (Table 1) were selected after reviewing their English abstract. Studies were included if they had a cross-sectional, cohort, or case-control design and evaluated salivary profile, including the mean/median salivary nickel or chromium level. Review articles, letters to editor or case reports, and articles with full texts that were not accessible free of charge or that had not reported the mean or median salivary concentration of ions were excluded. The most important inclusion criteria were as follows: 1) patients with no previous history of orthodontic treatment, 2) presence of controls without previous/current orthodontic treatment, 3) patients and controls without any systemic disease or dental problem, and 4) saliva samples collected from patients and controls after rinsing the mouth. 
Table 1. Population, intervention/exposure, comparison, and outcome of the included studies.

\begin{tabular}{cc}
\hline Criteria & Description \\
\hline Population & Eligible patients for fixed orthodontic treatment \\
Intervention/exposure & Fixed orthodontic treatment \\
Comparison & Before vs after intervention/patients vs controls \\
Outcome & Salivary nickel and/or chromium levels \\
\hline
\end{tabular}

\subsection{Data Extraction from Studies}

One author (M.S.) reviewed the articles, screened the titles and abstracts based on the aforementioned criteria, and extracted the required data. Two authors (M.R. \& M.S.) independently rechecked the full text of the screened studies. Data collected from each study included the name of the first author, year of publication, country, number of patients evaluated, percentage of male patients, mean age of patients, and salivary nickel or chromium levels. These data were rechecked by another author (M.M.I.).

\subsection{Quality Evaluation}

The quality of the questionnaire was evaluated using the Newcastle-Ottawa scale [18], in which the maximum total score is 10 for a cross-sectional study and 9 for a cohort or case-control study. The quality evaluation was done by two authors (M.R. \& M.S.) for each study until a consensus was reached via discussion.

\subsection{Statistical Analyses}

A random-effect meta-analysis was done by the Review Manager 5.3 (The Cochrane Collaboration, Oxford, United Kingdom) using the mean difference (MD) and 95\% confidence interval (CI). Heterogeneity between the estimates was evaluated by the $Q$ and $I 2$ statistic. For the $Q$ statistic, heterogeneity was considered if $P<0.1$, and $P$-value (2-sided) $<0.05$ was considered statistically significant in this meta-analysis. The heterogeneity $\left(\mathrm{I}^{2}\right)$ statistic yields results ranging from zero to $100 \%$; 0 to $25 \%$ indicates lack of heterogeneity, $25 \%$ to $50 \%$ indicates moderate heterogeneity, $50 \%$ to $75 \%$ indicates large heterogeneity, and $75 \%$ to $100 \%$ indicates extreme heterogeneity [19]. In addition, the publication bias was evaluated by the funnel plot analysis and the Begg's and Egger's tests. We used a formula for estimation of the mean and standard deviation if the study reported median plus range [20], or median plus interquartile range [21]. The unit of measurement of salivary nickel or chromium level was microgram per liter $(\mu \mathrm{g} / \mathrm{L})$.

\section{Results}

\subsection{Characteristics of Included Studies}

The search of the four databases yielded 451 studies (Figure 1). After excluding the duplicates, 283 studies were screened, from which 262 were not relevant according to the set criteria. Therefore, the full texts of 21 studies were assessed for eligibility. After reading the full texts of 21 studies, 7 studies were excluded with reasons (two studies had invalid data, one case-control study had lost data, one case-control study had reported the level of ions in the mass of saliva instead of volume, two randomized clinical trials had heterogeneous methods, and one study had different number of patients in each treatment period). Finally, 14 articles were included and analyzed in this meta-analysis. 


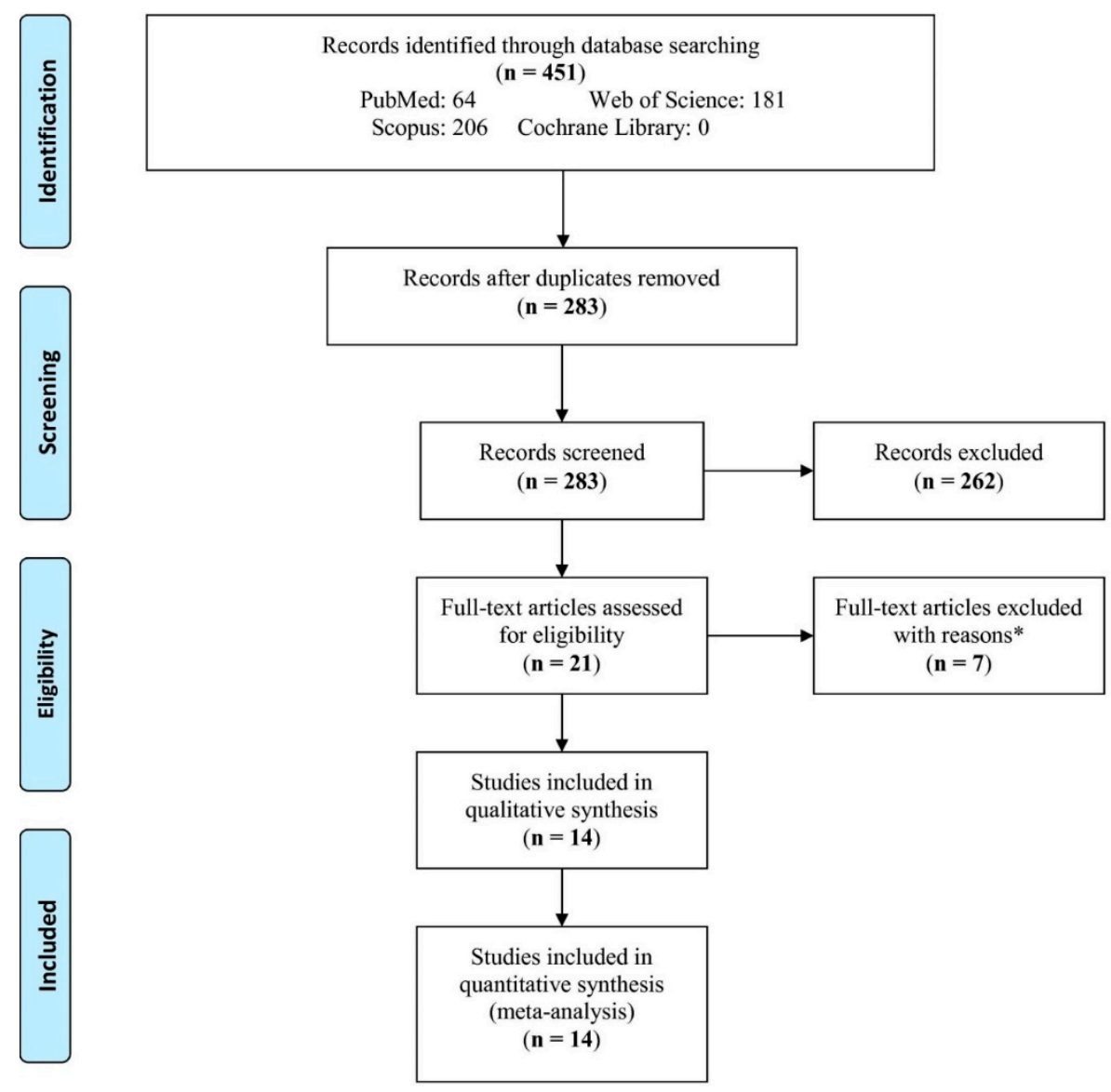

*Two studies had invalid data. One case-control study had lost data. One case-control study reported the value of ions in the mass of saliva, not volume. Two randomized clinical trials had heterogeneous methods. One study had different number of patients in the treatment periods.

Figure 1. Flowchart of literature search and study selection.

Table 2 shows the characteristics of 14 studies included in this meta-analysis. Four studies had been conducted in India [2,10,22,23], three in Iran [24-26], one in Norway [5], one in Turkey [13], one in Brazil [11], one in Greece [4], one in Morocco [6], one in Saudi Arabia [15], and one in Germany [1]. Two studies [1,22] reported the median (quartile) of the salivary level of ions, two studies $[4,5]$ reported the median (range), and one study [6] reported the mean (range) values. Three studies $[2,6,23]$ had only evaluated one assessment period of orthodontic treatment. Three studies did not report the mean age $[1,2,11]$. Table 2 shows the mean age, age range, percentage of male and female patients, follow-up periods, analysis methods, and saliva sampling method in each study. 
Table 2. Characteristics of the studies included in this meta-analysis $(n=14)$.

\begin{tabular}{|c|c|c|c|c|c|c|c|c|c|}
\hline $\begin{array}{l}\text { The First } \\
\text { Author, Year }\end{array}$ & Country & $\begin{array}{l}\text { Type of } \\
\text { Study }\end{array}$ & $\begin{array}{l}\text { Participants } \\
\text { (n) }\end{array}$ & $\begin{array}{c}\text { Mean } \\
\text { Age/age } \\
\text { Range of } \\
\text { Patients, Year }\end{array}$ & $\begin{array}{l}\text { Percentage of } \\
\text { Male Patients }\end{array}$ & Outcome & Follow-Up & Analysis Method & Saliva Sampling \\
\hline $\begin{array}{c}\text { Kerosuo, } 1997 \\
{[5]}\end{array}$ & Norway & Cross-sectional & 47 & $12.4 / 8-30$ & 40.4 & $\begin{array}{l}\text { Salivary nickel \& } \\
\text { chromium }\end{array}$ & 1 day, 1 week, 1 month, & $\begin{array}{l}\text { Atomic absorption } \\
\text { spectrophotometry }\end{array}$ & NA/stimulated \\
\hline $\begin{array}{l}\text { Ağaoğlu, } 2001 \\
\text { [13] }\end{array}$ & Turkey & Cross-sectional & 100 & $19.5 / 12-33$ & 33 & $\begin{array}{l}\text { Salivary nickel \& } \\
\text { chromium }\end{array}$ & $\begin{array}{l}1 \text { week, } 1 \text { month, } 12 \\
\text { months, } 24 \text { months }\end{array}$ & $\begin{array}{l}\text { Atomic absorption } \\
\text { spectrophotometry }\end{array}$ & Fasting/unstimulated \\
\hline $\begin{array}{c}\text { Matos de } \\
\text { Souza, 2008 } \\
\text { [11] }\end{array}$ & Brazil & Cross-sectional & 30 & $-/ 20-26$ & 26.7 & $\begin{array}{l}\text { Salivary nickel \& } \\
\text { chromium }\end{array}$ & $\begin{array}{c}10 \text { min and less, } 1 \text { day, } 1 \\
\text { week, } 1 \text { month, } 2 \\
\text { months }\end{array}$ & $\begin{array}{l}\text { Atomic absorption thermal } \\
\text { electric spectrophotometry }\end{array}$ & Fasting/NA \\
\hline $\begin{array}{l}\text { Singh, } 2008 \\
\text { [22] }\end{array}$ & India & Cross-sectional & 10 & $17.5 / 14-24$ & 30 & $\begin{array}{l}\text { Salivary nickel \& } \\
\text { chromium }\end{array}$ & 1 week, 3 weeks, & $\begin{array}{l}\text { Atomic absorption thermal } \\
\text { electricspectrophotometer }\end{array}$ & NA/stimulated \\
\hline $\begin{array}{l}\text { Petoumenou, } \\
2009[4]\end{array}$ & Greece & Cross-sectional & 18 & $14.9 / 12-18.1$ & 44.5 & Salivary nickel & $\begin{array}{l}\text { Up to } 8 \text { weeks after the } \\
\text { placement of the wires }\end{array}$ & Atomic absorption spectrometry & Nonfasting/unstimulated \\
\hline $\begin{array}{l}\text { Sahoo, } 2011 \\
\quad[10]\end{array}$ & India & Cross-sectional & 20 & $21.5 / 18-25$ & 0 & $\begin{array}{l}\text { Salivary nickel \& } \\
\text { chromium }\end{array}$ & 1 day, 1 week, 1 month & Atomic absorption spectrometry & NA/unstimulated \\
\hline $\begin{array}{c}\text { Amini, } 2012 \\
{[24]}\end{array}$ & Iran & $\begin{array}{l}\text { Prospective } \\
\text { cohort }\end{array}$ & 20 & 16/14-23 & 40 & $\begin{array}{l}\text { Salivary nickel \& } \\
\text { chromium }\end{array}$ & 6 months, 12 months & $\begin{array}{l}\text { Atomic absorption } \\
\text { spectrophotometry }\end{array}$ & Fasting / unstimulated \\
\hline $\begin{array}{l}{ }^{*} \mathrm{Amini}, 2012 \\
{[26]}\end{array}$ & Iran & Case-control & 28 vs. 28 & $\begin{array}{c}17.5 / 16-19 \text { vs. } \\
18.2 / 14-22\end{array}$ & 42.8 vs. 42.8 & $\begin{array}{l}\text { Salivary nickel \& } \\
\text { chromium }\end{array}$ & 12-18 months & $\begin{array}{l}\text { Atomic absorption } \\
\text { spectrophotometry }\end{array}$ & NA/NA \\
\hline $\begin{array}{c}\text { Ousehal, } 2012 \\
{[6]}\end{array}$ & Morocco & Cross-sectional & 16 & $\sim 19.1 / 13-25$ & 50 & Salivary nickel & $\begin{array}{l}10 \text { min and less, } 2 \\
\text { months }\end{array}$ & $\begin{array}{l}\text { Inductively coupled } \\
\text { plasma-mass spectrometry }\end{array}$ & NA/unstimulated \\
\hline $\begin{array}{l}* \text { Talic, } 2013 \\
\quad[15]\end{array}$ & $\begin{array}{l}\text { Saudi } \\
\text { Arabia }\end{array}$ & $\begin{array}{l}\text { Case-control } \\
\text { (cross-sectional) }\end{array}$ & 39 vs. 50 & 18.1 vs. 22 & 41 vs. 48 & $\begin{array}{l}\text { Salivary nickel \& } \\
\text { chromium }\end{array}$ & 1-32 months & $\begin{array}{l}\text { Inductively coupled } \\
\text { plasma-mass spectrometry }\end{array}$ & NA/unstimulated \\
\hline $\begin{array}{l}\text { Yassaei, } 2013 \\
{[25]}\end{array}$ & Iran & Cohort & 32 & $\sim 15.3 / 11-24$ & NA & $\begin{array}{l}\text { Salivary nickel \& } \\
\text { chromium }\end{array}$ & $\begin{array}{l}3 \text { weeks, } 3 \text { months, } 6 \\
\text { months }\end{array}$ & Atomic absorption spectrometry & NA/unstimulated \\
\hline $\begin{array}{l}\text { Nayak, } 2015 \\
\text { [2] }\end{array}$ & India & Cross-sectional & 30 & $-/ 10-25$ & 50 & $\begin{array}{l}\text { Salivary nickel \& } \\
\text { chromium }\end{array}$ & $\begin{array}{l}10 \text { min and less, } 12 \\
\text { months }\end{array}$ & $\begin{array}{l}\text { Inductively coupled } \\
\text { plasma-mass spectrometry }\end{array}$ & NA/NA \\
\hline $\begin{array}{c}\text { Kumar, } 2016 \\
{[23]}\end{array}$ & India & Cross-sectional & 10 & $\mathrm{NA} / 14-23$ & 50 & $\begin{array}{l}\text { Salivary nickel \& } \\
\text { chromium }\end{array}$ & 10 days, 1 month & $\begin{array}{l}\text { Inductively coupled } \\
\text { plasma-optical emission } \\
\text { spectrometry }\end{array}$ & NA/NA \\
\hline Gölz, 2016 [1] & Germany & $\begin{array}{l}\text { Prospective } \\
\text { cohort }\end{array}$ & 30 & $-/ 10-13$ & NA & Salivary nickel & $\begin{array}{l}\text { Up to } 8 \text { weeks after the } \\
\text { placement of the wires }\end{array}$ & $\begin{array}{c}\text { Inductively coupled } \\
\text { plasma-mass spectrometry }\end{array}$ & Nonfasting/unstimulated \\
\hline
\end{tabular}




\subsection{Salivary Nickel and Chromium Levels (before versus after Fixed Orthodontic Treatment)}

\subsubsection{Nickel Levels in 10 Time Periods}

Figure 2 shows the salivary nickel levels in 10 time periods before and after the insertion of fixed appliances. The pooled MD was estimated for the periods of $10 \mathrm{~min}$ or less $(\mathrm{MD}=-11.5 \mu \mathrm{g} / \mathrm{L}, 95 \%$ $\mathrm{CI}=-16.92$ to $-6.07 ; P<0.0001), 1$ day $(\mathrm{MD}=-1.38 \mu \mathrm{g} / \mathrm{L}, 95 \% \mathrm{CI}=-1.97$ to $-0.80 ; P<0.00001)$, 1 week $(\mathrm{MD}=1.02 \mu \mathrm{g} / \mathrm{L}, 95 \% \mathrm{CI}=-2.16$ to $4.21 ; P=0.53), 3$ weeks $(\mathrm{MD}=-0.81 \mu \mathrm{g} / \mathrm{L}, 95 \% \mathrm{CI}=$ -3.04 to $1.43 ; P=0.48), 1$ month $(\mathrm{MD}=5.53 \mu \mathrm{g} / \mathrm{L}, 95 \% \mathrm{CI}=-1.42$ to $12.48 ; P=0.12), 2$ months (MD $=3.42 \mu \mathrm{g} / \mathrm{L}, 95 \% \mathrm{CI}=0.83$ to $6.00 ; P=0.010), 3$ months $(\mathrm{MD}=2.63 \mu \mathrm{g} / \mathrm{L}, 95 \% \mathrm{CI}=0.77$ to $4.49 ; P=$ $0.006), 6$ months $(\mathrm{MD}=-0.03 \mu \mathrm{g} / \mathrm{L}, 95 \% \mathrm{CI}=-1.87$ to $1.80 ; P=0.97), 12$ months $(\mathrm{MD}=-0.66 \mu \mathrm{g} / \mathrm{L}$, $95 \% \mathrm{CI}=-4.15$ to $2.83 ; P=0.71)$, and 24 months $(\mathrm{MD}=0.01 \mu \mathrm{g} / \mathrm{L}, 95 \% \mathrm{CI}=-0.95$ to $0.97 ; P=0.98)$ after fixed orthodontic treatment compared to baseline (before fixed orthodontic treatment). There was no heterogeneity in 10 min or less, 1 day, 3 weeks, 2 months, and si6x months, whereas extreme heterogeneity was found in 1 week and 1 month, and a large heterogeneity was observed in 12 months. There were significant differences in time periods of 10 min or less, 1 day, 2 months, and 3 months. In time periods of 10 min or less and 1 day, salivary nickel level was higher after treatment compared to before treatment, but in periods of 2 months and 3 months, salivary nickel level after treatment was less than that before treatment.

\subsubsection{Chromium Levels in 10 Time Periods}

Figure 3 shows the salivary chromium levels in 10 time periods after the insertion of fixed appliances. The pooled MD was estimated for the time periods of $10 \mathrm{~min}$ or less $(\mathrm{MD}=-12.51 \mu \mathrm{g} / \mathrm{L}$, $95 \% \mathrm{CI}=-42.47$ to $-6.07 ; P=0.42), 1$ day $(\mathrm{MD}=-6.25 \mu \mathrm{g} / \mathrm{L}, 95 \% \mathrm{CI}=-12.00$ to $-0.49 ; P=0.03), 1$ week $(\mathrm{MD}=-2.07 \mu \mathrm{g} / \mathrm{L}, 95 \% \mathrm{CI}=-3.88$ to $-0.26 ; P=0.03), 3$ weeks $(\mathrm{MD}=-1.10 \mu \mathrm{g} / \mathrm{L}, 95 \% \mathrm{CI}=$ -2.84 to $0.65 ; P=0.22), 1$ month $(\mathrm{MD}=1.16 \mu \mathrm{g} / \mathrm{L}, 95 \% \mathrm{CI}=-2.68$ to $5.00 ; P=0.56), 2$ months $(\mathrm{MD}=$ $0.12 \mu \mathrm{g} / \mathrm{L}, 95 \% \mathrm{CI}=-0.16$ to $0.40 ; P=0.41), 3$ months $(\mathrm{MD}=-0.81 \mu \mathrm{g} / \mathrm{L}, 95 \% \mathrm{CI}=-2.40$ to $0.78 ; P=$ $0.32), 6$ months ( $\mathrm{MD}=-0.78 \mu \mathrm{g} / \mathrm{L}, 95 \% \mathrm{CI}=-2.16$ to $0.61 ; P=0.27), 12$ months $(\mathrm{MD}=0.72 \mu \mathrm{g} / \mathrm{L}, 95 \%$ $\mathrm{CI}=-1.21$ to $2.65 ; P=0.47)$, and 24 months $(\mathrm{MD}=0.22 \mu \mathrm{g} / \mathrm{L}, 95 \% \mathrm{CI}=-0.09$ to $0.53 ; P=0.16)$ after insertion compared to baseline (before fixed orthodontic treatment). There was no heterogeneity in 3 weeks and 6 months after treatment, whereas an extreme heterogeneity was found in 1 day, 1 week, and 12 months and a large heterogeneity in $10 \mathrm{~min}$ or less and 1 month after treatment. There were significant differences in time periods of 1 day and 1 week; salivary chromium level was found to be higher after treatment than before treatment in both periods.

\subsubsection{Nickel Levels in Five Time Periods}

Figure 4 shows salivary nickel levels in five time periods after the insertion of fixed appliances. The pooled MD was estimated immediately after placement of the bands and brackets $(\mathrm{MD}=-36.79$ $\mu \mathrm{g} / \mathrm{L}, 95 \% \mathrm{CI}=-56.08$ to $-17.51 ; P=0.0002)$, after two weeks $(\mathrm{MD}=8.27 \mu \mathrm{g} / \mathrm{L}, 95 \% \mathrm{CI}=3.75$ to 12.78 ; $P=0.0003)$, before placement of archwires $(\mathrm{MD}=-20.27 \mu \mathrm{g} / \mathrm{L}, 95 \% \mathrm{CI}=-38.24$ to $-2.31 ; P=0.03)$, immediately after placement of archwires $(\mathrm{MD}=12.46 \mu \mathrm{g} / \mathrm{L}, 95 \% \mathrm{CI}=8.45$ to $16.46 ; P<00001)$, four weeks after placement of wires $(\mathrm{MD}=8.14 \mu \mathrm{g} / \mathrm{L}, 95 \% \mathrm{CI}=4.66$ to $11.63 ; P<00001)$, and eight weeks after placement of wires compared to baseline (before fixed orthodontic treatment). There was a large heterogeneity in the first and third periods, whereas there was no heterogeneity in the second, fourth, and fifth periods. There were significant differences in all periods such that the salivary nickel level was higher after placement of the bands and brackets and immediately after placement of archwires compared to baseline (before treatment), but this value was lower after two weeks, before placing the archwires, four weeks after placement of wires, and four weeks after placement of wires compared to before treatment. 


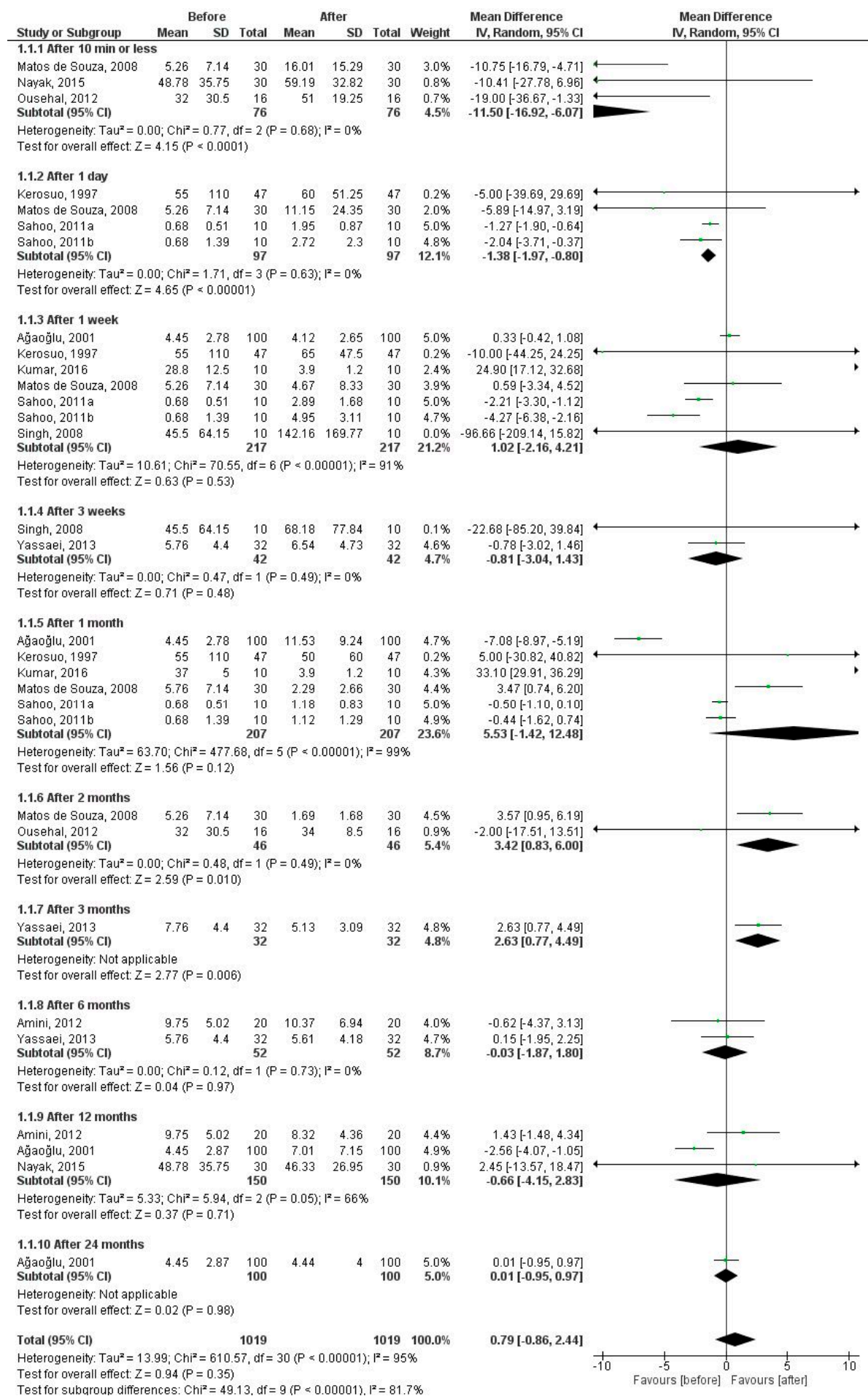

Figure 2. Forest plot of the random effect of salivary nickel levels in patients under fixed orthodontic treatment (before versus after treatment). 


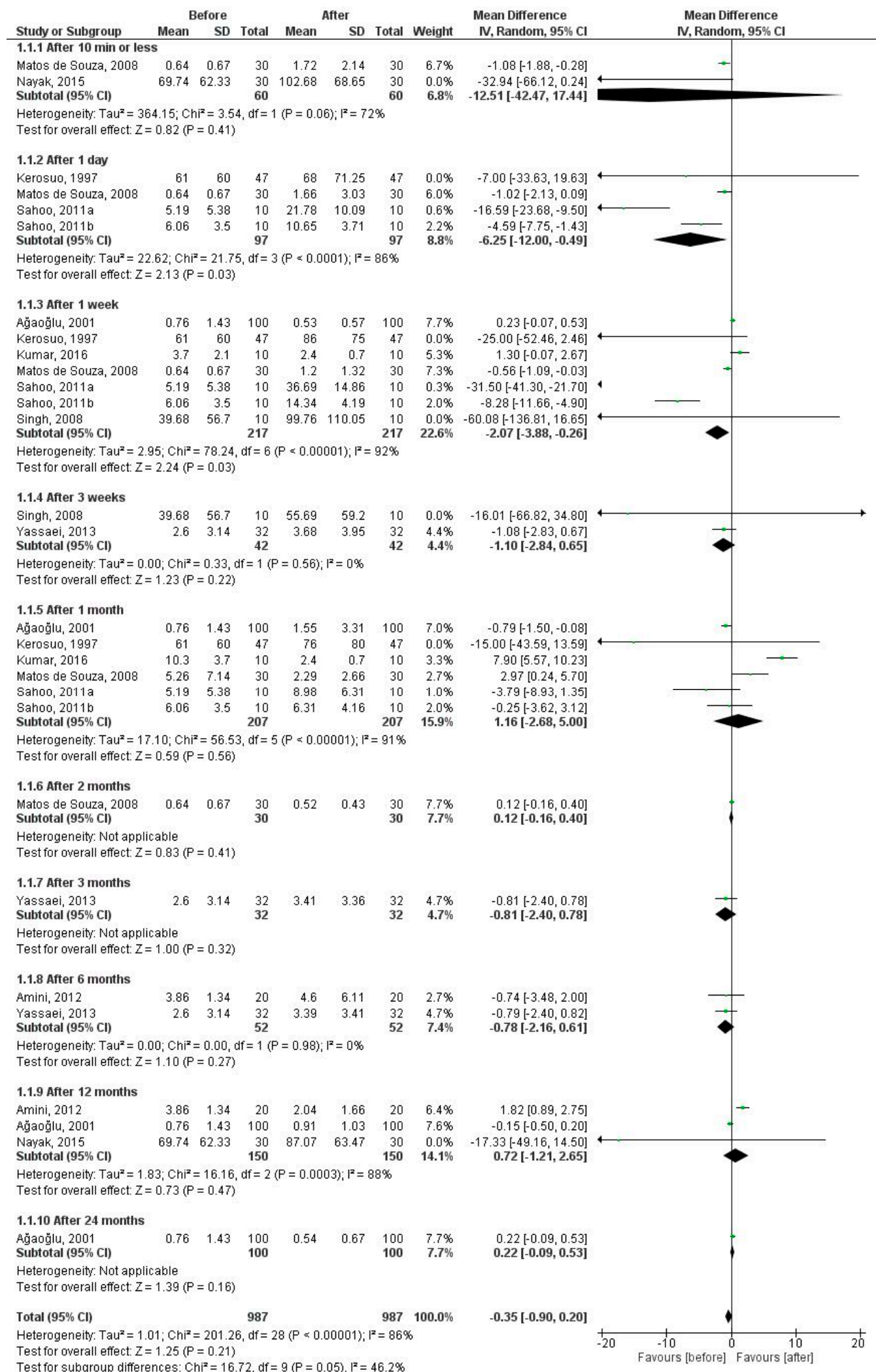

Figure 3. Forest plot of the random effect of salivary chromium levels in patients under fixed orthodontic treatment (before versus after treatment). 


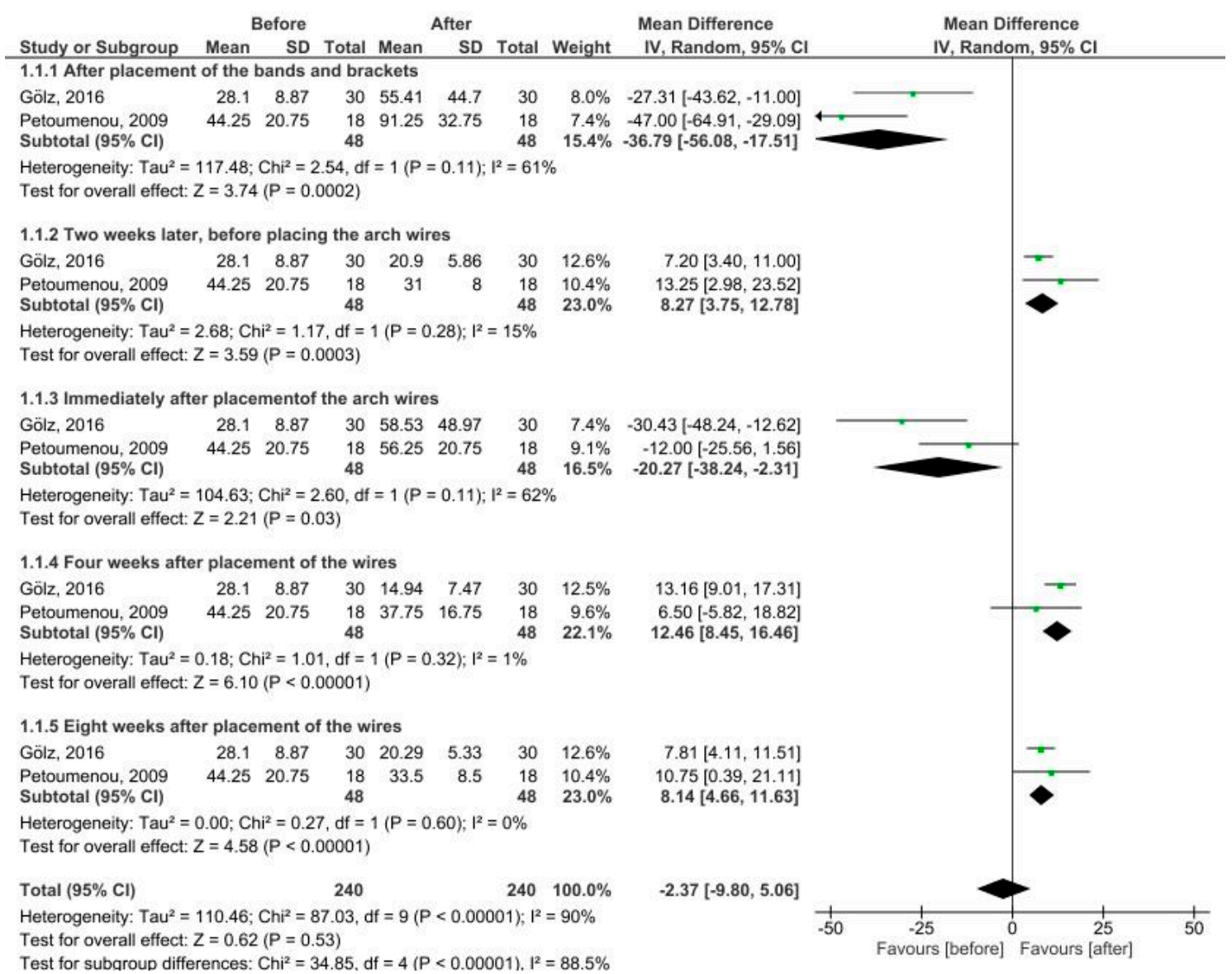

Figure 4. Forest plot of the random effect of salivary nickel levels in patients under fixed orthodontic treatment (before versus after treatment).

\subsection{Salivary Nickel and Chromium Levels (Case-Control Studies)}

\subsubsection{Nickel Levels}

Three studies showed MD of the salivary nickel in patients under fixed orthodontic treatment compared to controls (Figure 5). The pooled MD was estimated at $3.14 \mu \mathrm{g} / \mathrm{L}(95 \% \mathrm{CI}=-0.92$ to 7.21 ; $P=0.13)$ in patients compared to controls. There was a moderate heterogeneity.

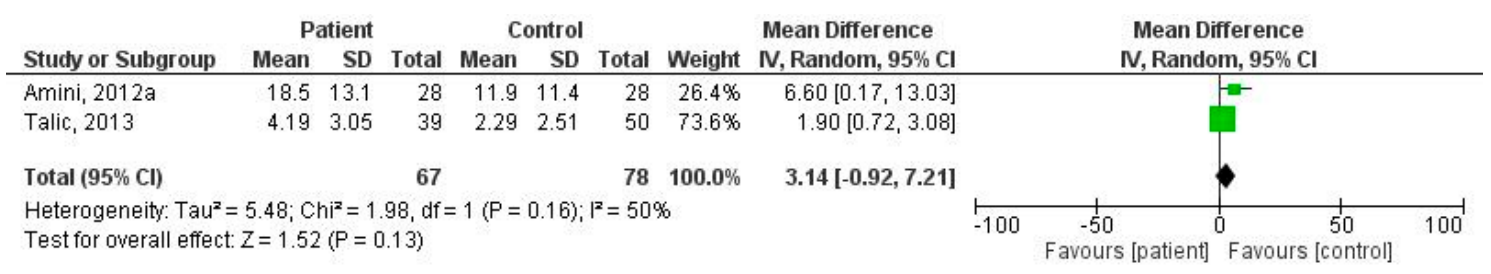

Figure 5. Forest plot of the random effect of salivary nickel levels in patients under fixed orthodontic treatment in case-control studies.

\subsubsection{Chromium Levels}

Figure 6 shows MD of the salivary chromium level in patients compared to controls in three studies. The pooled MD was estimated at $-0.09 \mu \mathrm{g} / \mathrm{L}(95 \% \mathrm{CI}=-0.85$ to $0.67 ; P=0.82)$ in patients compared to controls. There was a large heterogeneity. 


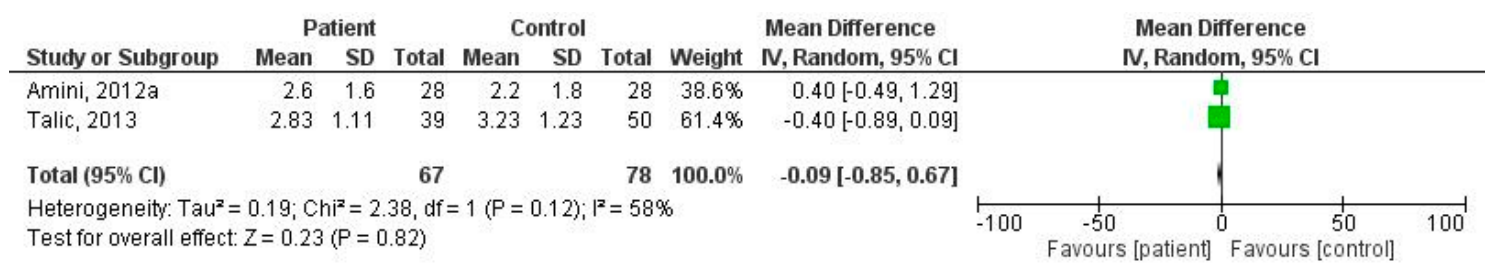

Figure 6. Forest plot of the random effect of salivary chromium levels in patients under fixed orthodontic treatment in case-control studies.

\subsubsection{Quality Evaluation}

Table 3 shows the quality score for each study included in the meta-analysis. The mean score was 7.78 for cross-sectional, 6.67 for cohort, and 7.50 for case-control studies.

Table 3. Quality ratings for the studies included on the basis of Newcastle-Ottawa quality assessment scale $(\mathrm{n}=14)$.

\begin{tabular}{lllll}
\hline First Author, Publication Year & Selection & Comparability & Outcome & Total Score \\
\hline Kerosuo, 1997 [5] & 4 & 1 & 3 & 8 \\
Ağaoğlu, 2001 [13] & 4 & 2 & 3 & 9 \\
Matos de Souza, 2008 [11] & 3 & 1 & 3 & 7 \\
Singh, 2008 [22] & 3 & 1 & 3 & 7 \\
Petoumenou, 2009 [4] & 4 & 2 & 3 & 9 \\
Sahoo, 2011 [10] & 3 & 2 & 3 & 8 \\
Ousehal, 201 [6] & 3 & 2 & 3 & 8 \\
Nayak, 2015 [2] & 3 & 0 & 3 & 6 \\
Kumar, 2016 [23] & 3 & 2 & 3 & 8 \\
Mean score (cross-sectional studies) & & & & 7.78 \\
Amini, 2012 [24] & 2 & 2 & 3 & 7 \\
Yassaei, 2013 [25] & 2 & 2 & 3 & 7 \\
Gölz, 2016 [1] & 2 & 2 & 2 & 6 \\
Mean score (cohort studies) & & & & 6.67 \\
Amini, 2012 [26] & 4 & 2 & 2 & 8 \\
Talic, 2013 [15] & 3 & 2 & & 7 \\
Mean score (case-control studies) & & & 2.50 \\
\hline
\end{tabular}

\subsection{Publication Bias}

Figure 7A shows the evaluation of publication bias among the included studies on salivary nickel levels. Begg's and Egger's tests did not reveal significant evidence of publication bias among the included studies on salivary nickel levels in time periods of $10 \mathrm{~min}$ or less and after 1 month. Begg's and Egger's tests revealed significant evidence of publication bias in periods of after one day and after one week. Regarding the periods of after 3 weeks, after 2 months, after 3 months, after 6 months, and after 24 months, Begg's test revealed no publication bias, and Egger's test could not be performed because only two studies were included. For the period of after 12 months, Begg's test revealed no publication bias, but Egger's test revealed a significant publication bias. Figure 7B shows evaluation of the publication bias among the included studies on salivary chromium level. Begg's and Egger's tests did not reveal significant evidence of publication bias among the included studies on salivary chromium levels in periods of after 1 month and after 12 months. Begg's and Egger's tests revealed significant evidence of publication bias among the included studies on salivary nickel level in time periods of after one day and after one week. As for the period of 10 min or less, after 3 weeks, after 2 months, after 3 months, after 6 months, and after 24 months, Begg's test revealed no publication bias, and Egger's test could not be performed because only two studies were included. 

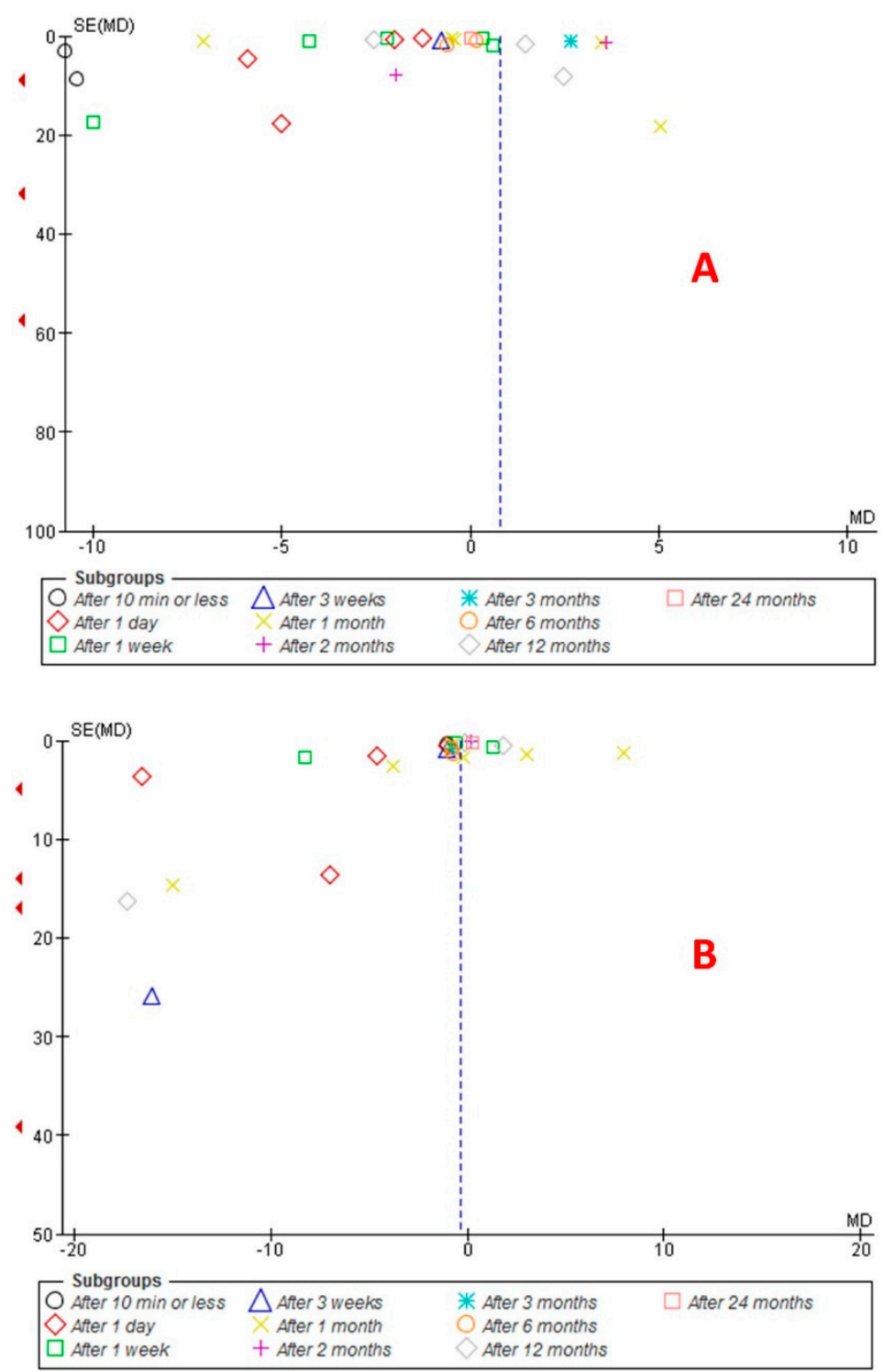

Figure 7. Funnel plot of the random effect of (A) salivary nickel levels and (B) salivary chromium levels in patients under fixed orthodontic treatment (before versus after treatment).

\section{Discussion}

This meta-analysis evaluated the salivary nickel and chromium levels in patients under fixed orthodontic treatment for different periods of time compared to controls. The salivary nickel level was higher in periods of $10 \mathrm{~min}$ or less and 1 day from the insertion of appliance as well as after placement of the bands and brackets and immediately after placement of archwires compared to baseline, while the salivary nickel level was lower than the baseline (pretreatment) value in periods of after two months and three months from the insertion of appliance as well as two weeks after the insertion of appliance except for wires, and four weeks after the placement of wires. The salivary chromium level was higher than the baseline pretreatment value in periods of one day and one week after the insertion of appliance. In this meta-analysis, the mean concentration of chromium in the reviewed studies ranged from 0.68 to $142.16 \mu \mathrm{g} / \mathrm{L}$ and the mean concentration of nickel ranged from 0.52 to $102.68 \mu \mathrm{g} / \mathrm{L}$.

It has been shown that nickel and chromium ions can cause hypersensitivity reactions, dermatitis, and asthma; thus, nickel and chromium ions released from stainless-steel orthodontic bands, brackets, and wires are likely to cause allergic reactions $[5,27]$. The composition of saliva may be affected by 
many physiological variables such as time of the day, health conditions, diet [28], and salivary flow rate [29]. The emotional state also affects the salivary flow rate; for example, anxiety and depression can cause dry mouth [30]. The large variations in nickel levels reported in studies might be explained by the differences in saliva composition and $\mathrm{pH}$, which are influenced by various physiological and environmental factors such as time of the day, diet, health, and mental conditions as well as nickel adhesion to epithelial cells, bacteria, macromolecules of the saliva $[9,11,31-33]$, and the method of sampling (stimulated versus unstimulated saliva collection) [7,19,34]. Differences in the methodology, sample size, and time periods of sample collection may explain generally lower nickel concentrations in patients treated with fixed appliances [10]. High metal ion levels are found one to two weeks after exposure to metal appliances, which will later return to their initial levels $[4,5,13,35]$. Orthodontic appliances release ions into the oral environment [1,11,12] more intensely in the first months of placement of the appliance [1,10]. In the present study, in the periods of $10 \mathrm{~min}$ or less and 1 day after fixed orthodontic treatment, nickel levels significantly increased compared to baseline. In addition, chromium levels significantly increased at one day and one week after the initiation of treatment compared to baseline. Therefore, a passivation layer is required to reduce the release of ions. In addition, reduction in salivary level of nickel after two and three months of treatment with a peak at one month shows that the maximum release of nickel probably occurs earlier than one month but the environmental and psychological conditions of the patients undergoing treatment immediately after placement of bands, brackets, and archwires may affect the release of nickel; these conditions may be variable in different studies.

An in vitro study demonstrated the corrosion potential of orthodontic appliances [2]. Some studies showed nickel [36-40] and chromium [11,37,39,41] release from orthodontic brackets. However, when placed in the oral cavity; the appliances are mechanically activated to facilitate tooth movement. The archwire movement and bracket friction may lead to greater corrosion and increase the release of metal ions from the orthodontic appliances [2]. Corrosion of orthodontic alloys may lead to the release of sizeable amounts of nickel and chromium into the saliva [42,43]. In the present study, salivary nickel levels significantly increased in two time periods, namely after placement of the bands and brackets and immediately after placement of archwires. Therefore, corrosion can be an effective factor to increase salivary nickel levels in fixed orthodontic treatment. Among the six case-control studies included in this meta-analysis, two studies $[15,26]$ showed significantly higher nickel level in patients under orthodontic treatment than controls and two studies $[32,44]$ did not show any significant difference between the two groups, but two other studies [9,34] showed a lower level in patients compared to controls $(P>0.05)$. Also, evaluation of chromium level in five studies revealed that three studies $[26,34,44]$ reported a higher level in patients compared to controls $(P>0.05)$ while two other studies $[9,15]$ reported a lower level in patients compared to controls. Meta-analysis of two eligible case-control studies $[15,26]$ showed a higher level of nickel, but a lower level of chromium without a significant difference between the two groups of patients and controls. The difference in salivary nickel and chromium levels among in vivo or in vitro studies and also between in vivo and in vitro studies can be due to the difference in ions released from orthodontic appliances. Based on the conclusions of reviewed studies, type of appliances (bands, brackets, and archwires) having the different amounts of ions in their structure, history of allergy in patient, period of treatment, saliva $\mathrm{pH}$, and diet were effective factors in the level of ions. The lack or presence of heterogeneity in time periods cannot have a reasonable explanation due to the small number of participants or studies in some time periods. Therefore, in order to have a strong clinical result, more homogeneous studies having the similar times should be undertaken. The small number of case-control studies included in this meta-analysis can affect the results as a bias. Further studies and clinical trials are required in this respect. Moreover, future studies should pay close attention to the method of saliva sampling and the follow-up time to minimize bias.

Limitations of this meta-analysis included different protocols of saliva sampling in different studies, different analyses of the saliva samples in different studies, different percentages of males and 
females in the studies, different age range of patients, different time periods of evaluation, and small number of participants in the majority of studies.

\section{Conclusions}

Overall, within the limitations of this meta-analysis, it can be concluded that corrosion of fixed orthodontic appliances leads to elevated salivary nickel and chromium levels early after the initiation of orthodontic treatment. The small amount of nickel released from orthodontic appliances in cross-sectional/cohort and case-control studies may support the opinion of an orally-induced tolerance level against nickel early after the initiation of orthodontic treatment. Randomized clinical trials controlling for the factors affecting the composition of saliva are recommended with a larger sample size and among different ethnic groups.

Author Contributions: M.M.I. designed the study. M.S. contributed to the conception of the study and drafted the manuscript. H.R.M., M.R., \& M.S. reviewed the information of the articles. M.M.I. \& M.S. critically edited the manuscript. All authors have read and approved the final paper prior to its submission.

Funding: The authors gratefully acknowledge the Research Council of Kermanshah University of Medical Sciences (grant number 97449) for the financial support.

Conflicts of Interest: The authors declare no conflict of interest.

\section{References}

1. Gölz, L.; Knickenberg, A.C.; Keilig, L.; Reimann, S.; Papageorgiou, S.N.; Jäger, A.; Bourauel, C. Nickel ion concentrations in the saliva of patients treated with self-ligating fixed appliances: A prospective cohort study. J. Orofac. Orthop. 2016, 77, 85-93. [CrossRef] [PubMed]

2. Nayak, R.S.; Khanna, B.; Pasha, A.; Vinay, K.; Narayan, A.; Chaitra, K. Evaluation of Nickel and Chromium Ion Release During Fixed Orthodontic Treatment Using Inductively Coupled Plasma-Mass Spectrometer: An In Vivo Study. J. Int. Oral Health 2015, 7, 14-20. [PubMed]

3. Andreasen, G.F.; Hilleman, T.B. An evaluation of 55 cobalt substituted Nitinol wire for use in orthodontics. J. Am. Dent. Assoc. 1971, 82, 1373-1375. [CrossRef] [PubMed]

4. Petoumenou, E.; Arndt, M.; Keilig, L.; Reimann, S.; Hoederath, H.; Eliades, T.; Jäger, A.; Bourauel, C. Nickel concentration in the saliva of patients with nickel-titanium orthodontic appliances. Am. J. Orthod. Dentofac. Orthop. 2009, 135, 59-65. [CrossRef] [PubMed]

5. Kerosuo, H.; Moe, G.; Hensten-Pettersen, A. Salivary nickel and chromium in subjects with different types of fixed orthodontic appliances. Am. J. Orthod. Dentofac. Orthop. 1997, 111, 595-598. [CrossRef]

6. Ousehal, L.; Lazrak, L. Change in nickel levels in the saliva of patients with fixed orthodontic appliances. Int. Orthod. 2012, 10, 190197. [CrossRef] [PubMed]

7. Arab, S.; Nouhzadeh Malekshah, S.; Abouei Mehrizi, E.; Ebrahimi Khanghah, A.; Naseh, R.; Imani, M.M. Effect of Fixed Orthodontic Treatment on Salivary Flow, pH and Microbial Count. J. Dent. (Tehran) 2016, 13, $18-22$.

8. Mikulewicz, M.; Chojnacka, K. Release of metal ions from orthodontic appliances by in vitro studies: A systematic literature review. Biol. Trace Elem. Res. 2011, 139, 241-256. [CrossRef] [PubMed]

9. Kocadereli, L.; Atac, P.A.; Kale, P.S.; Ozer, D. Salivary nickel and chromium in patients with fixed orthodontic appliances. Angle Orthod. 2000, 70, 431-434. [PubMed]

10. Sahoo, N.; Kailasam, V.; Padmanabhan, S.; Chitharanjan, A.B. In-vivo evaluation of salivary nickel and chromium levels in conventional and self-ligating brackets. Am. J. Orthod. Dentofac. Orthop. 2011, 140, 340-345. [CrossRef] [PubMed]

11. Matos de Souza, R.; Macedo de Menezes, L. Nickel, chromium and iron levels in the saliva of patients with simulated fixed orthodontic appliances. Angle Orthod. 2008, 78, 345-350. [CrossRef] [PubMed]

12. Amini, F.; Harandi, S.; Mollaei, M.; Rakhshan, V. Effects of fixed orthodontictreatment using conventional versus metal-injection molding brackets onsalivary nickel and chromium levels: A double-blind randomized clinical trial. Eur. J. Orthod. 2015, 37, 522-5230. [CrossRef] [PubMed]

13. Ağaoğlu, G.; Arun, T.; Izgi, B.; Yarat, A. Nickel and chromium levels in the saliva and serum of patients with fixed orthodontic appliances. Angle Orthod. 2001, 71, 375-379. [PubMed] 
14. Moffa, J.P. Council on Dental Materials, Instruments, and Equipment. Biological effects of nickel-containing dental alloys. J. Am. Dent. Assoc. 1982, 104, 501-505. [PubMed]

15. Talic, N.F.; Alnahwi, H.H.; Al-Faraj, A.S. Nickel and chromium levels in the saliva of a Saudi sample treated with fixed orthodontic appliances. Saudi Dent. J. 2013, 25, 129-133. [CrossRef] [PubMed]

16. Eliades, T.; Bourauel, C. Intraoral aging of orthodontic materials: The picture we miss and its clinical relevance. Am. J. Orthod. Dentofac. Orthop. 2005, 127, 403-412. [CrossRef] [PubMed]

17. Moher, D.; Liberati, A.; Tetzlaff, J.; Altman, D.G.; PRISMA Group. Preferred reporting items for systematic reviews and meta-analyses: The PRISMA statement. PLoS Med. 2009, 6, e1000097. [CrossRef] [PubMed]

18. Wells, G.A.; Shea, B.; O'Connell, D.; Robertson, J.; Peterson, J.; Welch, V.; Losos, M.; Tugwell, P. The Newcastle-Ottawa Scale (NOS) for Assessing the Quality of Non-Randomised Studies in Meta-Analyses; Ottawa Hospital Research Institute: Ottawa, ON, Canada, 2011; Available online: http:/ / www.ohri.ca/programs / clinical_epidemiology / oxford.asp (accessed on 12 January 2016).

19. Egger, M.; Smith, G.; Schneider, M.; Minder, C. Bias in meta-analysis detected by a simple, graphical test. BMJ 1997, 315, 629-634. [CrossRef] [PubMed]

20. Hozo, S.P.; Djulbegovic, B.; Hozo, I. Estimating the mean and variance from the median, range, and the size of a sample. BMC Med. Res. Methodol. 2005, 5, 13. [CrossRef] [PubMed]

21. Wan, X.; Wang, W.; Liu, J.; Tong, T. Estimating the sample mean and standard deviation from the sample size, median, range and/or interquartile range. BMC Med. Res. Methodol. 2014, 14, 135. [CrossRef] [PubMed]

22. Singh, D.P.; Sehgal, V.; Pradhan, K.L.; Chandna, A.; Gupta, R. Estimation of nickel and chromium in saliva of patients with fixed orthodontic appliances. World J. Orthod. 2008, 9, 196-202. [PubMed]

23. Kumar, R.V.; Rajvikram, N.; Rajakumar, P.; Saravanan, R.; Deepak, V.A.; Vijaykumar, V. An Accurate Methodology to detect Leaching of Nickel and Chromium Ions in the Initial Phase of Orthodontic Treatment: An in vivo Study. J. Contemp. Dent. Pract. 2016, 17, 205-210. [CrossRef] [PubMed]

24. Amini, F.; Rakhshan, V.; Mesgarzadeh, N. Effects of long-term fixed orthodontic treatment on salivary nickel and chromium levels: A 1-year prospective cohort study. Biol. Trace Elem. Res. 2012, 150, 15-20. [CrossRef] [PubMed]

25. Yassaei, S.; Dadfarnia, S.; Ahadian, H.; Moradi, F. Nickel and chromium levels in the saliva of patients with fixed orthodontic appliances. Orthodontics (Chic.) 2013, 14, e76-e81. [CrossRef] [PubMed]

26. Amini, F.; Jafari, A.; Amini, P.; Sepasi, S. Metal ion release from fixed orthodontic appliances-An in vivo study. Eur. J. Orthod. 2012, 34, 126-130. [CrossRef] [PubMed]

27. Bass, J.K.; Fine, H.; Cisneros, G.J. Nickel hypersensitivity in the orthodontic patient. Am. J. Orthod. Dentofac. Orthop. 1993, 103, 280-285. [CrossRef]

28. Ferguson, D.B. Current diagnostic uses of saliva. J. Dent. Res. 1987, 66, 420-424. [CrossRef] [PubMed]

29. Dawes, $\mathrm{C}$. The effects of flow rate and duration of stimulation on the concentration of protein and the main electrolytes in human submandibular saliva. Arch. Oral Biol. 1974, 19, 887-895. [CrossRef]

30. Bardow, A.; Lynge Petersen, A.M.; Nauntofte, B. Saliva. In Clinical Oral Physiology; Miles, T.S., Nauntofte, B., Svensson, P., Eds.; Quintessenz Verlags-GmbH: Berlin, Germany, 2004; pp. 18, 22-24, 35.

31. Mikulewicz, M.; Chojnacka, K. Trace metal release from orthodontic appliances by in vivo studies: A systematic literature review. Biol. Trace Elem. Res. 2010, 137, 127-138. [CrossRef] [PubMed]

32. Fors, R.; Persson, M. Nickel in dental plaque and saliva in patients with and without orthodontic appliances. Eur. J. Orthod. 2006, 28, 292-297. [CrossRef] [PubMed]

33. Menezes, L.M.; Quintao, C.A.; Bolognese, A.M. Urinary excretion levels of nickel in orthodontic patients. Am. J. Orthod. Dentofac. Orthop. 2007, 131, 635-638. [CrossRef] [PubMed]

34. Eliades, T.; Trapalis, C.; Eliades, G.; Katsavrias, E. Salivary metal levels of orthodontic patients: A novel methodological and analytical approach. Eur. J. Orthod. 2003, 25, 103-106. [CrossRef] [PubMed]

35. Barrett, R.D.; Bishara, S.E.; Quinn, J.K. Biodegradation of orthodontic appliances. Part I. Biodegradation of nickel and chromium in vitro. Am. J. Orthod. Dentofac. Orthop. 1993, 103, 8-14. [CrossRef]

36. Tahmasbi, S.; Sheikh, T.; Hemmati, Y.B. Ion Release and Galvanic Corrosion of Different Orthodontic Brackets and Wires in Artificial Saliva. J. Contemp. Dent. Pract. 2017, 18, 222-227. [PubMed]

37. Tahmasbi, S.; Ghorbani, M.; Masudrad, M. Galvanic Corrosion of and Ion Release from Various Orthodontic Brackets and Wires in a Fluoride-containing Mouthwash. J. Dent. Res. Dent. Clin. Dent. Prospects 2015, 9, 159-165. [CrossRef] [PubMed] 
38. Jithesh, C.; Venkataramana, V.; Penumatsa, N.; Reddy, S.N.; Poornima, K.Y.; Rajasigamani, K. Comparative evaluation of nickel discharge from brackets in artificial saliva at different time intervals. J. Pharm. Bioallied Sci. 2015, 7, S587-S593. [PubMed]

39. Mikulewicz, M.; Chojnacka, K.; Wołowiec, P. Release of metal ions from fixed orthodontic appliance: An in vitro study in continuous flow system. Angle Orthod. 2014, 84, 140-148. [CrossRef] [PubMed]

40. Sfondrini, M.F.; Cacciafesta, V.; Maffia, E.; Scribante, A.; Alberti, G.; Biesuz, R.; Klersy, C. Nickel release from new conventional stainless steel, recycled, and nickel-free orthodontic brackets: An in vitro study. Am. J. Orthod. Dentofac. Orthop. 2010, 137, 809-815. [CrossRef] [PubMed]

41. Sfondrini, M.F.; Cacciafesta, V.; Maffia, E.; Massironi, S.; Scribante, A.; Alberti, G.; Biesuz, R.; Klersy, C. Chromium release from new stainless steel, recycled and nickel-free orthodontic brackets. Angle Orthod. 2009, 79, 361-367. [CrossRef] [PubMed]

42. House, K.; Sernetz, F.; Dymock, D.; Sandy, J.R.; Ireland, A.J. Corrosion of orthodontic appliances-Should we care? Am. J. Orthod. Dentofac. Orthop. 2008, 133, 584-592. [CrossRef] [PubMed]

43. Hwang, C.J.; Shin, J.S.; Cha, J.Y. Metal release from simulated fixed orthodontic appliances. Am. J. Orthod Dentofac. Orthop. 2001, 120, 383-391. [CrossRef] [PubMed]

44. Lages, R.B.; Bridi, E.C.; Pérez, C.A.; Basting, R.T. Salivary levels of nickel, chromium, iron, and copper in patients treated with metal or esthetic fixed orthodontic appliances: A retrospective cohort study. J. Trace Elem. Med. Biol. 2017, 40, 67-71. [CrossRef] [PubMed]

(C) 2019 by the authors. Licensee MDPI, Basel, Switzerland. This article is an open access article distributed under the terms and conditions of the Creative Commons Attribution (CC BY) license (http:/ / creativecommons.org/licenses/by/4.0/). 